\title{
The Spirit of Charity and Compassion in Daoist Religion
}

\author{
Yanxia Zhao \\ Centre for Daoist Studies, University of Wales Trinity Saint David, United Kingdom
}

Copyright $(0) 2015$ Horizon Research Publishing All rights reserved.

\begin{abstract}
In the popularly understood sense, the concept of charity relates to an action of helping people who are in a poor or a sick situation, normally through the means of giving money or gifts. The concept was not limited in this way at its origin, however. More importantly, the concept has widened and developed to carry additional layers of meaning in recent years. This widening and developing can be seen from documents defining the term 'charity' that are being produced by differing countries and nations. A detailed list of charitable purposes (as defined in legal terms by the UK government under the Charities Act 2011) is particularly useful in this regard. It is within these newly developed layers of meaning that Daoism has a strong role to play in charitable works, as a religion with a spirit of charity and heart of compassion. The issue then is how to apply this charitable spirit and compassionate heart of Daoism to specific charitable actions in modern age.
\end{abstract}

Keywords Daoism, Religion, Charity, Compassion, Environmentalism, Yangsheng, Health, Longevity

\section{Introduction}

Charity, generally speaking, is related to the action of helping people who are in need, either poor or sick, or suffering in desperate conditions, through donations of money, or giving gifts. This concept also relates to the feeling of compassion that causes the giver to make such donations. Such interpretation of the term can be seen in English dictionaries such as the Longman Dictionary of Contemporary English [1] where 'charity' is expressed in three meanings: 1. Money or gifts given to help people who are poor, sick etc.; 2 . An organization that collects money or goods in order to help people who are poor, sick etc.; 3. A kind sympathetic attitude you have when judging or criticizing someone.(p.294). In the late $19^{\text {th }}$ century, when Charity law was formed in England [2], the 'commonly understood' sense of 'charity' was similarly defined as 'the relief of any form of necessity, destitution or helplessness which excites the compassion or sympathy of men, and so appeals to their benevolence for relief.'(1 AC 531, 572). However, the term did not have this narrow application in practice even in the Elizabethan period.[3](p.92-96).

A wider understanding is evident even in 1891, when the so-called four 'heads' of charity were introduced in the Commissioners for Special Purposes of Income Tax. There the commonly understood sense of charity occurs only in the 'first head' as shown in the chart below. It is therefore the much wider application of the concept of charity (and its application) that is of interest here. In particular, the aim is to track how the concept of charity has developed in the modern age, from the widely understood meaning cited above to a much broader one. This newer development of the concept will in turn bear witness to the unique contribution that could be made to the charitable work by the Daoist religion, a religion as a tradition with a spirit of charity and a heart of compassion. The connection of Daoism and the modern concept of charity will be discussed from three parts: the definition of charity in modern sense, the spirit of charity and heart of compassion in Daoism, and the possible way of transforming Daoist charitable spirit into modern charitable work.

\section{The Definition of Charity in the Modern Sense}

The concept of charity is not a fixed single notion but a notion with various understandings from the very beginning, and it is a notion keeps changing its definition in time. As stated in Defining Charity: A Literature Review [4], the legal meaning of 'charity' is distinct from the 'popularly understood' meaning above. This is a distinction composed of three elements [5]: First, the so called four 'heads' of charity, listed as the relief of the poor, aged or impotent; the advancement of education; the advancement of religion; and 'other purposes beneficial to the community'. Secondly, a purpose alleged to be charitable under the fourth head of charity must fall within (or be analogous to) one of the 10 specific charitable purposes listed in the preamble referenced; they are: the relief of the aged, poor and impotent; the maintenance of sick and maimed soldiers and mariners; the repair of bridges, ports, havens, causeways, churches, seabanks and highways; the maintenance of schools and colleges; the education and preferment of orphans; the relief, stock or maintenance of houses of correction; marriages of poor maids; the supportation, aid and help for young 
tradesmen, handicraftsmen and persons decayed; the relief or redemption of prisoners or captives; and the aid and ease of any poor inhabitants concerning payment of fifteens, setting out soldiers, and other taxes. Finally, case laws as practiced for centuries can also refine the parameters of charity. (p.124). According to the authors of Defining Review [4] this definition of charity had been under a renewed consideration by many countries since 1996, not only in in England and Wales, but also Scotland, Ireland, New Zealand, Canada and South Africa.

\section{New change in definition of charity}

In 2001, a formal inquiry into the 'Definition of Charities and Related Organisations' (Charities Definition Inquiry) was commissioned by the Australian Government to examine the issue in the context of the introduction of the Goods and Services Tax (GST), where three particular types of organization were clarified as having charitable status. As a result, in 2011 legislation was enacted defining charitable purpose in England and Wales. In this Charities Act [6], the definition of charity is seen throughout 13 charitable purposes. In order to see more clearly for what have been changed in the 13 charitable purposes defined by the UK Government in 2011 from the legal meaning of charity practised in England 200 years ago, a chart is created as below:

\begin{tabular}{|c|c|c|c|}
\hline $\begin{array}{l}\text { The four heads of } \\
\text { charity }\end{array}$ & $\begin{array}{l}10 \text { specific charitable purposes } \\
\text { listed in the preamble }\end{array}$ & $\begin{array}{l}13 \text { Charitable purposes as defined in } \\
2011\end{array}$ & Daoist spirit of charity \\
\hline \multirow{7}{*}{$\begin{array}{l}\text { 1. the relief of the } \\
\text { poor, aged or } \\
\text { impotent }\end{array}$} & \multirow{2}{*}{$\begin{array}{l}\text { 1. the relief of the aged, poor and } \\
\text { impotent; }\end{array}$} & 1. The prevention or relief of poverty & $\begin{array}{l}\text { Relief of the unhappy and loneliness of } \\
\text { the elderly }\end{array}$ \\
\hline & & \multirow{2}{*}{$\begin{array}{l}\text { 10. The relief of those in need, by reason } \\
\text { of youth, age, ill-health, disability, } \\
\text { financial hardship or other disadvantage }\end{array}$} & \multirow{2}{*}{$\begin{array}{l}\text { Relief of those who are in ill-health } \\
\text { and financial hardship caused by } \\
\text { illness }\end{array}$} \\
\hline & 8. the supportation, aid and help for & & \\
\hline & and persons decayed; & \multirow{2}{*}{$\begin{array}{l}\text { 6. The advancement of the arts, culture, } \\
\text { heritage or science. }\end{array}$} & \multirow{2}{*}{$\begin{array}{l}\text { The advancement of arts, culture, } \\
\text { heritage or science in the Daoist } \\
\text { tradition }\end{array}$} \\
\hline & 7. marriages of poor maids; & & \\
\hline & $\begin{array}{l}\text { 10. the aid and ease of any poor } \\
\text { inhabitants concerning payment of } \\
\text { fifteens, setting out soldiers, and } \\
\text { other taxes }\end{array}$ & \multirow{2}{*}{$\begin{array}{l}\text { 12. The promotion of the efficiency of } \\
\text { the armed forces of the Crown, or of the } \\
\text { efficiency of the police, fire and rescue } \\
\text { services or ambulance services }\end{array}$} & \multirow[t]{2}{*}{$\begin{array}{l}\text { The health and spiritual wellbeing of } \\
\text { those who are working in a dangerous } \\
\text { and abnormal situations }\end{array}$} \\
\hline & $\begin{array}{l}\text { 2.the maintenance of sick and } \\
\text { maimed soldiers and mariners }\end{array}$ & & \\
\hline \multirow{2}{*}{$\begin{array}{l}\text { 2. the advancement of } \\
\text { education }\end{array}$} & $\begin{array}{l}\text { 4.the maintenance of schools and } \\
\text { colleges; }\end{array}$ & \multirow{2}{*}{ 2. The advancement of education } & \multirow{2}{*}{$\begin{array}{l}\text { The advancement of Daoist Education } \\
\text { as a holistic system, from gaining } \\
\text { knowledge and skills to the cultivation } \\
\text { of a compassionate personality }\end{array}$} \\
\hline & $\begin{array}{l}\text { 5.the education and preferment of } \\
\text { orphans; }\end{array}$ & & \\
\hline $\begin{array}{l}\text { 3. the advancement of } \\
\text { religion }\end{array}$ & 3. the repair of the churches & 3.The advancement of religion & $\begin{array}{l}\text { The advancement of Daoism as a } \\
\text { religion for personal enlightenment }\end{array}$ \\
\hline \multirow{8}{*}{$\begin{array}{l}\text { 4. other purposes } \\
\text { beneficial to the } \\
\text { community }\end{array}$} & $\begin{array}{l}\text { 3. the repair of bridges, ports, } \\
\text { havens, causeways, churches, } \\
\text { seabanks and highways; }\end{array}$ & 5. The advancement of citizenship or & $\begin{array}{l}\text { The advancement of the Daoist } \\
\text { principle of nourishing life, to include } \\
\text { two basic elements: maintaining }\end{array}$ \\
\hline & $\begin{array}{l}\text { 6. the relief, stock or maintenance } \\
\text { of houses of correction; }\end{array}$ & & $\begin{array}{l}\text { personal good health, and smooth } \\
\text { relationships with others }\end{array}$ \\
\hline & \multirow{6}{*}{$\begin{array}{l}\text { 9. the relief or redemption of } \\
\text { prisoners or captives }\end{array}$} & $\begin{array}{l}\text { 8. The advancement of human rights, } \\
\text { conflict resolution or reconciliation or } \\
\text { the promotion of religious or racial } \\
\text { harmony or equality and diversity }\end{array}$ & $\begin{array}{l}\text { The advancement of happy longevity, } \\
\text { based on keeping harmony both within } \\
\text { and without, as an important aim of } \\
\text { Daoism }\end{array}$ \\
\hline & & $\begin{array}{l}\text { 4. The advancement of health or the } \\
\text { saving of lives }\end{array}$ & $\begin{array}{l}\text { The treasuring of life and its } \\
\text { nourishment in the lives of all forms as } \\
\text { the central themes of Daoism }\end{array}$ \\
\hline & & 7. The advancement of amateur sport & $\begin{array}{l}\text { The advancement of Daoyin } \\
\text { Gymnastics Taiji and Daoist Martial } \\
\text { Arts, as invented by Daoism for the } \\
\text { purpose of healthy longevity }\end{array}$ \\
\hline & & $\begin{array}{l}\text { 9. The advancement of environmental } \\
\text { protection or improvement }\end{array}$ & $\begin{array}{l}\text { The advancement of Daoism as a } \\
\text { nature-centred religion }\end{array}$ \\
\hline & & 11. The advancement of animal welfare; & $\begin{array}{l}\text { The advancement of equality among } \\
\text { different life forms as essential for } \\
\text { Daoism }\end{array}$ \\
\hline & & $\begin{array}{l}\text { 12. Any other purposes currently } \\
\text { recognised as charitable and any new } \\
\text { charitable purposes which are similar to } \\
\text { another charitable purpose }\end{array}$ & $\begin{array}{l}\text { The promotion of wellbeing as a } \\
\text { lifestyle, prevention of ill-health, } \\
\text { equality between genders and species, } \\
\text { and protection of the natural } \\
\text { environment }\end{array}$ \\
\hline
\end{tabular}


From this chart it can be seen that the traditional 'Four Heads of Charity' remain functional in the classification of modern charitable purposes even in contemporary times. However, the 10 charitable purposes originally legalized under this umbrella have widened out into a new total of 13 items, which differ from the older version in a number of significant ways: First, there are aspects which appear in the recent version that are not seen in the previous one. For examples, the advancement of health or the saving of lives (no.4); the advancement of amateur sport (no.7); the advancement of environmental protection or improvement (no.9) and the advancement of animal welfare (no.11), are all entirely new.

When analysed in greater detail, differences that add up to a many-layered understanding of the concept of charity can be also found in the newer version. For example, instead of the simple form of 'the supportation, aid and help for young tradesmen, handicraftsmen' and 'persons decayed', we see instead the widened concept of 'the advancement of the arts, culture, heritage or science' in the 2011 legislation. Another example is the 'the relief or redemption of prisoners or captives' that is currently replaced with the much more complex 'advancement of human rights, conflict resolution or reconciliation or the promotion of religious or racial harmony or equality and diversity'. Thus, in the new version, not only have human rights issues, but also the promotion of wider issues, such as conflict resolution or reconciliation, the promotion of religious or racial harmony, equality and diversity in religions and so on, are all included. Thus conceptual enlargement is also seen from the change in content relating to soldiers as compared to the current version; that is, the 'setting out of soldiers' and 'the maintenance of sick and maimed soldiers and mariners' are now replaced by 'the promotion of the efficiency of the armed forces of the Crown, or of the efficiency of the police, fire and rescue services or ambulance services'.

Beside these, some specific purposes listed previously have now been replaced by more enlightened and community-based intentions. For example, 'the repair of bridges, ports, havens, causeways, churches, seabanks and highways' has been replaced by 'advancement of religion' and 'the advancement of citizenship or community development' of the current version. In a more radical way, items concerning 'the maintenance of schools and colleges' and 'the education and preferment of orphans' have been replaced by the newer 'advancement of education'.

Although there is a continuous theme running through both versions of charitable purpose with similar emphasis, they are presented in different ways. For example, the theme of 'relief of the poor, aged and impotent' is presented in the previous version through the following items: the marriage of poor maids; supportation, aid and help for young tradesmen, handicraftsmen and persons decayed; aid and ease of any poor inhabitants concerning payment of fifteens, setting out soldiers, and other taxes, and the maintenance of sick and maimed soldiers and mariners. In the new version of the 13 charitable purposes, these themes are continued, but through four clearer expressions of the intent as follows: prevention or relief of poverty; the relief of those in need, by reason of youth, age, ill-health, disability, financial hardship or other disadvantage; the advancement of the arts, culture, heritage or science; the promotion of the efficiency of the armed forces of the Crown, or of the efficiency of the police, fire and rescue services or ambulance services. Indeed, items summarized in the current version have actually moved beyond the theme of 'relief of the poor, aged and impotent', as wider issues for human wellbeing are recognised as needing prevention, change, advancement or promotion.

From above analysis it can be seen that the changes from previous charitable purposes to the current interpretations and intentions are extensive. And all these changes have paved way for the connection of Daoism with the newly developed concept of charity. How could such extensive change happen? And how is Daoism connected to this newly developed understanding of charity? These are what we are going to discuss in next session.

\section{Daoism and the new concept of charity}

e the focus of charitable work that has paved the way for the connection of Daoism with the modern conceptualisation of charity. From the chart above it can be seen that the traditional 'Four Heads of Charity' remain functional in the classification of modern charitable purposes even in contemporary times. However, the 10 charitable purposes originally legalized under this umbrella have widened out into a new total of 13 items, which differ from the older version in a number of significant ways. First, there are aspects which appear in the recent version that are not seen in the previous one. For examples, the advancement of health or the saving of lives (no.4); the advancement of amateur sport (no.7); the advancement of environmental protection or improvement (no.9) and the advancement of animal welfare (no.11) are all entirely new.

When analysed in greater detail, differences that add up to a many-layered understanding of the concept of charity can be also found in the newer version. For example, instead of the simple form of 'the supportation, aid and help for young tradesmen, handicraftsmen' and 'persons decayed', we see instead the widened concept of 'the advancement of the arts, culture, heritage or science' in the 2011 legislation. Another example is the 'the relief or redemption of prisoners or captives' that is currently replaced with the much more complex 'advancement of human rights, conflict resolution or reconciliation or the promotion of religious or racial harmony or equality and diversity'. Thus, in the new version, not only have human rights issues but also the promotion of wider issues such as conflict resolution or reconciliation, the promotion of religious or racial harmony, equality and diversity in religions, and so on are included. Thus conceptual enlargement is also seen from the change in content relating to soldiers as compared to the current version; that is, the 'setting out of soldiers' and 'the maintenance of sick and maimed soldiers and mariners' are now replaced by 'the promotion of the efficiency of the 
armed forces of the Crown, or of the efficiency of the police, fire and rescue services or ambulance services'.

Beside these, some specific purposes listed previously have now been replaced by more enlightened and community-based intentions. For example, 'the repair of bridges, ports, havens, causeways, churches, seabanks and highways' has been replaced by 'advancement of religion' and 'the advancement of citizenship or community development' of the current version. In a more radical way, items concerning 'the maintenance of schools and colleges' and 'the education and preferment of orphans' have been replaced by the newer 'advancement of education'.

Although there is a continuous theme running through both versions of charitable purpose with similar emphasis, they are presented in different ways. For example, the theme of 'relief of the poor, aged and impotent' is presented in the previous version through the following items: the marriage of poor maids; supportation, aid and help for young tradesmen, handicraftsmen and persons decayed; aid and ease of any poor inhabitants concerning payment of fifteens, setting out soldiers, and other taxes, and the maintenance of sick and maimed soldiers and mariners. In the new version of the 13 charitable purposes, these themes are continued, but through four clearer expressions of the intent as follows: prevention or relief of poverty; the relief of those in need, by reason of youth, age, ill-health, disability, financial hardship or other disadvantage; the advancement of the arts, culture, heritage or science; the promotion of the efficiency of the armed forces of the Crown, or of the efficiency of the police, fire and rescue services or ambulance services. Indeed, items summarized in the current version have actually moved beyond the theme of 'relief of the poor, aged and impotent', as wider issues for human wellbeing are recognised as needing prevention, change, advancement or promotion.

\section{Why is the change of the definition needed?}

People may argue that the spirit of charity is in the heart of every religion of this world, as Christian Smith and Hilary Davidson [7] have observed,

An ancient Hebrew proverb teaches that, 'One man gives freely, yet gains even more; another withholds unduly, but ends up impoverished'. The Buddha teaches, 'Giving brings happiness at every stage of its expression.' A Hindu proverb holds that, 'they who give have all things, they who withhold have nothing.' And Jesus of Nazareth teaches, 'Whoever tried to keep his life will lose it and whoever loses his life will preserve it.' (p.1).

Why do you only connect Daoism with modern understanding of charity? Do you suggest there are some special values that only Daoism can contribute to the modern concept of charity? My answer to these questions is 'yes'; the reason why I choose Daoism as a study case is indeed because of the special characteristic of Daoism in connecting the new issues and new background where the new concept of charity has developed.
The new social structure requested the change of the concept of charity paves the way for the immergence of Daoist contribution to modern charity. In comparison with the old society where the popular charity is prevailed, the social structure has changed dramatically in nowadays. In the past, the structure of human society was very simple: normally only one race, one religion and one culture in each social system. However, modern industry and globalization have connected the whole world together (financially at least) as one enormous global village. Under such circumstances, migrating from one society to another (usually for financial and educational reasons) has become commonplace; thus, it is not only probable, but actually unavoidable that people from different religious and cultural backgrounds are attempting to live side-by-side. Because of this new principle of free movement, clashes and conflicts among people from different nationalities and cultures (with different racial origins and religions) are inevitable when they encounter each other; therefore, the advancement of religion and culture, the promotion of human equality and diversity (and the like) are becoming more and more necessary in contemporary times, in an effort to achieve harmonious relations. In the meantime, because of the constant needs of communication among different nations and political systems for the purposes of expanding the economy, political power, or the exchange of culture and religion, world standards of justice and human rights need to be established and promoted. This need in turn makes the promotion of human rights (and equality between races and genders) more and more important to the aims and purposes of charitable works. As an individual focused tradition, Daoism, on the one hand emphasizes the importance of personal wellbeing, and in the meantime puts stress on the harmonious relationship among individuals, and between individual and society. This will allow the equality and diversity among individuals to be promoted and the harmony among different cultures, political ideologies, and societies to be enhanced. This then ensures the connection of Daoism with modern sense of charity.

The profound change in understanding of human relationship with nature and animals has also paved the way for the potential contribution of Daoism in the field of charity. From the traditional Christian perspective, human beings are the controllers and managers of the world. They have the right to exploit nature, to abuse animals, and to manage the world in whatever way they wish; as Thomas Aquinas [8] has said, because God has subjected all things to man's power, it does not matter how man behaves to animals. (p.1481). Using Immanuel Kant's words [9], 'As far as animals are concerned we have no direct duties. Animals are not self-conscious and are they merely as a means to an end. That end is Man'. (p.239). Under such an understanding, the world is designed as a hierarchical order with man (Adam) at its pinnacle exactly as Aristotle suggested [10], 'Plants exist for the sake of animals, and brute beasts for the sake of man.' Man therefore had lordship not only over nature and animals, but also over those at lower levels, such as wives, sons and 
slaves. Thus, not only animal rights could be ignored, but also those of humans at lower levels.

However, this largely male-driven attitude is forced to change alongside successive legislation. And with this, the continually growing awareness of the need for equality and justice among humans; between male and female; between different races; between different levels of social status, and between humans and animals. In particular, recognition is increasing of how vital it is for humans to co-exist peacefully with their natural environment, with other cultures and societies, and with their own appeared. Also increasing is the recognition that human beings are only part of nature, and the other beings in the world, including animals and their natural environments) also have a right to co-exist with the humans race. Thus, new aims of enhancing animal welfare and protecting the natural environment are also input into charitable purposes. As a tradition with a natural centred worldview, Daoism not only views the status and rights of humans from a holistic perspective, but also encourages human individuals to establish a harmonious relationship with her/his natural and social environment, but also with the other species on earth and in the universe. This has made Daoism more modern relevance to modern concept of charity.

The enlargement of the definition of 'the poor, the sick, and the impotent' in both its connotations and its extension has made Daoism more valuable to the concept of charity in modern sense. In the past, to be 'poor' usually meant financial hardship at a survival level in the lives of humans, as individuals and as families. In the same way, to be 'sick' referred to the dysfunction of the physical operational system; with 'impotence' referring to the disability or handicap of the physical body. However, it seems that all these definitions have widened to include much more than survival. For instance, to be 'poor' in the newer sense refers to inability to access the necessary education or train for employability. To be 'sick' refers not only to the dysfunction of the body but also the disorder of mind or a problem of mental mindset. In the same way, the notion of 'impotence' has also been widened from physical disability or handicap to a concept of being psychologically disordered or disadvantaged. In such a context, to provide only sufficient money to survive in a state of poverty is therefore no longer enough. The provision of proper education is needed to acquire the necessary knowledge and skills to function effectively in one's work and social life; the provision of special mental and psychological training is equally vital to ensure human wellbeing and longevity. When all these purposes become more and more important for modern charitable pursuits, Daoism, as a tradition to emphasize on the high quality of longevity life through nourishing individual life, prevention of personal health, and self- care one's physical and mental wellbeing, will be able to provide special contribution to fulfil those newly developed health related charitable purposes in the concept of charity. This has made Daoism a special value and contribution toward the modern concept of charity.
The problem appeared in the modern practice of charity calls people to re-evaluate essential Daoist principle and it potential positive role in modern charitable field. Although, as Chak Kwan Chan [11] has rightly pointed out, charity has always enjoyed a positive image (p.266), and there is a 'compassion boom' of people helping others (p.2) in modern age; for example, according to Patrick Gorvington [12], CEO of the federal Corporation for National and Community Service, almost 90 percent of American adults are involved personally or financially in the charity industry (p.2), yet as Robert D Lupton [12] has pointed out, there is a actively perpetuate problem which people always trying to refuse and avoid, that is, "while we are very generous in charitable giving, much of that money is either wasted or actually harms the people it is targeted to help.' (p.1):

For all our efforts to eliminate poverty - our entitlements, our programs, our charities - we have succeeded only in creating a permanent underclass, dismantling their family structures, and eroding their ethic of work. And our poor continue to become poorer. (p.3).

Indeed, as the author of Dead Aid, Dambisa Moyo [12] has investigates, Aid, though intended to promote health, has actually becomes 'the disease of which it pretends to be the cure'. (3). This indicates that good intensions not necessary bring good result, it can translate into ineffective care or even harm! (p.2).

In fact, For most of the modern charities, because of their central focus is to collect money or gift and then helping to deliver these gifts to those in need, therefore, it is suggested that they rarely concentrate sufficiently on the vital work of helping the needy to grow their own potential to enable them to help themselves out of their difficulties. Chak Kwan Chan [11] has shown this problem in a detail way. He says, since the motives behind philanthropy are vary, ranging from self-interest to altruism; and more importantly, prestige and power in particular can earned through fund-raising activities, for example, 'Some donors have ever been known to manipulate conditions of poverty in order to improve their public image and social status' (p.267), the practice of charity in Hongkong Media charitable organization are problematic. This problem first can be manifested through the fact that the social status of donors and recipients as portrayed in the social service columns of the two newspapers was grossly unequal, with obvious sign that "the donors were accorded high social recognition for their charitable contributions', while 'the recipients, in the contrast as being weak, helpless and desperate'. This has made the poor had to stigmatise and degrade themselves in exchange for assistance; using Chan's words, 'The loss of privacy and the lowering of self-esteem were the price they [the recipients] had to pay for seeking help from the newspaper charity.' (p.271). More importantly, it can be also manifested through the fact that the newspapers' charity can only provide emergency relief for a particular need at a particular point in time, and 'They were unable to provide 
effective assistance to recipients suffering from long-term and multiple needs.' (P.273). Based on his research and practical work, Robert D Lupton [12] has also recognized that,

For all our efforts to eliminate poverty - our entitlements, our programme, our charities - we have succeeded only in creasing a permanent underclass, dismantling their family structures, and eroding their ethic of work. And our poor continue to become poorer. (p.3).

And religiously motivated charity is often the most irresponsible. Our free food and clothing distribution encourages ever-growing handout lines, diminishing the dignity of the poor while increasing their dependency. We converge on inner-city neighbours to plant flowers and pick up trash, bruising the pride of residents who have the capacity (and responsibility) to beautify their own environments. (p.4).

Based on that Lupton [12] suggests that " Giving those in need what they could be gaining from their own initiative may well be the kindest way to destroy people' (p.4); and 'what appears to be extrtavagant, selfless, even sacrificial investments from caring benefactors may well be exposed as large scale misappropriations of charitable resources.' (p.6). Different from these problematic charitable works, Daoism, as a tradition to focus on the development of individual's full potentials and capabilities in both cultivation of personality and problem-solving, can not only provide more effective assistance to recipients in helping themselves developing their own capability in dealing their own problems and in satisfying their own long-term and multiple needs.

In short, alongside modernization, and technical and scientific advancement, there are new issues that had never been putting into concern legislators in the past emerged. Grave concerns on issues such as health care, environmental protection, the rights of both humans and animals and even of other life forms, have therefore become crucial matters for those legislating for the future wellbeing and protection of our planet. It is the change that all things that can improve the quality of human life and can protect life in general are under central concern, and the change that all things that can promote the sustainability of Mother Earth and the natural environment have now become the focus of charitable work, which have paved the way for the connection of Daoism with the modern conceptualisation of charity. Based on these changes, Daoism has now become a tradition that can offer effective principles in line with almost all charitable purposes listed under 2011 legislation.

\section{Spirit of Charity and Heart of Compassion in Daoism}

According to Jonathan Edwards [13], the word 'charity' as used in the New Testament is of much more extensive signification than as it is used generally in common discourse. 'So that by Charity, in the New Testament, is meant the very same thing as Christian love; and though it be more frequently used for love to men, yet sometimes it is used to signify not only love to men, but love to God' (p.2). Based on such an understanding, charity has become a necessary part of Christian salvation. Different from Christianity, Daoism does not claim the salvation of others being the centre of its focus; instead enlightening oneself first and then others is encouraged. However, this none-salvation focus does not necessarily indicate that there is no spirit of charity and heart of compassion in Daoism. On the contrary, the spirit of charity is higher in level and the heart of compassion is bigger in scale in Daoism. This can be seen through the concept of Dao and the three treasures of Daoism, as well as the Daoist notion of equality, and the Daoist focus on healthy longevity life.

\section{Concept of Dao and the heart of charity in Daoism}

Daoist Religion is comprised of two words; 'Dao' and 'Jiao' in Chinese. Dao is the source, the root, the origin of the universe, and the principle underlying all myriad things; while Jiao is teaching of the wisdom and principle of the Dao. The two words Dao and Jiao combined together refers to the use of the wisdom of the Dao to transform oneself (as well as others) from a perplexed situation to an enlightened one through knowing the true nature of oneself and the world.

The central concept of Daoism is to attain unity with the Dao itself in order to return to the root, source and origin of things. This process of Dao attainment is one of gradual transformation and completion that is seen at many levels in myriad life forms and beings. Yet there is a general rule can be applied to every form of existence, that is, to follow the Dao of Nature. In chapter 25 of the Dao De Jing, Laozi [14] suggest: 'Humans follow the Earth, the Earth follows the Heaven, and Heaven follows the Nature.' This is to suggest that the way of humans is to follow the way of the Earth; and the Way of the Earth is to follow the Way of Heavens, and the Way of Heavens is to follow the Way of Nature. The way of earth is to rear and support things without claim of credits: [14]

Great Tao is everywhere; it can be left or right. Ten thousands [forms] owe their existence to her but she does not disown them; she makes them become beings but does not take possession of them; she loves and rears the ten thousands things but makes no claim to be master over them (chapter 34).

Thus, the virtue of the Dao in manifestation of the way of earth is therefore 'to generate them [myriad things] but not lay claim to them; to support them but never lean upon them; to let them grow but never control them'(chapter 10). Thus, as a practitioner of the Dao, one needs to act in exactly the same way as that of the Dao manifested through the way of the earth, that is, to follow the three charitable principles manifested by the way of earth: generating with no claim, nurturing with no ownership, and facilitating/accelerating 
based on an altruistic love with no intention of control.

Laozi used to differentiate the way of heaven and the way of humans in chapter 77 of Dao Dejing [14] saying that 'the way of Heaven reduces what has too much to complete what does not have enough,' while the way of Men 'reduces what does not have enough in order to offer it to what has too much.' Thus, as a practitioner of the Dao, one should follow the way of heaven in a sense of being capable of offering to a world in need whatever he/she has in surplus. Based on this giving of surplus, Dao Dejing [14] encourages people to engage directly in charitable deeds: 'the way of Heaven has no favourites, it harmonises steadfastly with those who are doing good deeds' (chapter 79).

Then, what is the way of nature? As the innate of nature is spontaneity, none-action, and supporting, the way of nature requires the Dao followers to perform charitable action in a natural way and according the inner need of the person who is under a charitable help. The natural way of support is to grow a seed to its full potential, and to provide what is in need for a life to fulfil its development. This is not usually what modern charitable organisations would do. From my perspective, to offer a direct aid in the form of money and gifts is a relatively easy work, and therefore should be categorised (in Daoist terms) as 'low level charitable performance'. From Daoist perspective, the provision of money or things for people in need is only a short-term solution; such a solution can neither provide help for long-term needs, nor for the enabling of individuals and organisations to deal with future problems. More importantly, this kind of help can even produce unfortunate side-effects for the recipients, as being observed by Chan and Lupton in previous sessions. They may entirely rely on donations from the outside world instead of developing their own abilities to resolve their economic problems, for example. It is for this reason that some scholars call for a re-think of so-called charitable works, which (in some cases) may indeed worsen the situation of poverty. One such example is Richard Stupart, [15]who (speaking of the ' 7 worst international aid ideas') cites the philosopher Zizek [16], declaring that 'donations to charity are hypocritical':

The act of all-included charity, in the end, does little more but work to sustain the coffee grower's unequal place in the grand order of human economics. It's better than nothing, to be sure, but it's a long way short of truly helping anyone to a life like yours.

So a charitable work based on the natural way should not only provide help for immediate survival of the person in need, but also focus upon the personal growth of human beings in order to develop their own skills and potential. This kind of charity would be higher in level from a Daoist perspective, as its focus is no longer on the immediate material needs of the recipients, but instead on cultivating the recipients' skills and capabilities to enable them to resolve their problems from an understanding of roots and causes. It is in such a manner that the central concept of Daoism, the Dao, expresses its spirit of charity and heart of compassion.

\section{Three Treasures and the spirit of charity in Daoism}

The centrality of spirit of charity and heart of compassion can be further strengthened by the three treasures of Daoism: namely, the 'Ci' (慈, kindness, or parental love), the 'Jian' (俭 simplicity, frugality, thriftiness), and the 'Bu gan wei tianxia xian' (不敢为天下先 not leading the world), as Laozi explains: [17] 'Here are my three treasures. Guard and keep them! The first is pity; the second, frugality; the third, dare not to lead the world.' (p.71)

Why, then, can these three qualities be regarded as treasures? In answer to this question, Laozi [14] declares that: '[it is only] $\mathrm{Ci}$ that can make people truly brave; [it is only] jian that can enable human beings to spread their surplus abundance widely; [it is only] bu gan wei tianxia xian that is truly able to allow things to accomplish their full growth [and potential]' (chapter 67). In my opinion, the three treasures of Daoism can not only ensure that the spirit of charity and the heart of compassion remain seated in the centre of Daoism, but also the Daoist charity to be practised in a higher and a purer level.

$C i$ as a parental love can ensure a higher level performance of charity. For instance, the ' $\mathrm{Ci}$ '(慈) will ensure that charitable work is carried out in a gentle, kind, and compassionate way. As a term that refers to the love and kindness that parents display towards their children, ' $\mathrm{Ci}$ ' is usually defined as a generous, unconditional love that does not ask for repayment. To offer a parental love to people in need can on the one hand avoid the charge of being 'as cold as charity', and on the other hand can also generate bold actions in offering help to the needy in ways that one may not dare to risk in normal everyday life. The love of parents from this perspective is a pure and a full-hearted compassion that is far beyond the feeling of mere sympathy. Thus, neither arrogance nor pity will enter such a love. Charity performed in this way will bring a feeling of contentment to the benefactor, with no potential harm to the recipient. Charity performed in this way is thus at a high level of performance.

In many cases through human history, charitable actions may have been delivered in a cold and arrogant way, thus wounding the dignity of the recipient. Indeed, individuals with strong self-esteem might choose to stay in a situation of suffering rather than to accept help which is offered with cold disdain, as explained in the Book of Rites: [18] A man with a pure heart will 'not eat food handed over in a contemptuous manner' (zhonggong 2). For some, this kind of hurt may turn into a feeling of bitter hatred, which might in turn cause unanticipated catastrophes such as riots, uprisings or even wars.

Indeed, humans are beings endowed with high sensitivities, who need to be respected and loved even during their hard times. Thus, if charitable works are carried out by the benefactor in a contemptuous manner, not only is the value of charity reduced, but also the beneficiary's dignity is offended. Daoism believes [14] that 'the way of Heaven is to benefit without hurt, while the way of the sages is to act without striving [for reward]' (chapter 81). Hence, from the 
Daoist perspective, charitable acts should be undertaken in a spirit of parental love, with pure kindness and compassion, with the sole purpose of helping recipients to realise their full potentiality, with no call for recognition of that help; just as Heaven will withdraw herself when her charitable purpose has been achieved, a Dao follower should also withdraw when his/her charitable offer is complete without claiming credit. As declared in the Dao Dejing: [14] 'the Sage relies on non-action activity, carries out wordless teaching; although ten thousand things are worked upon by him, yet he does not disown them; he rears them yet does not lay claim to them; he works on them yet does not lean upon them, and he achieves success but does not claim the merit' (chapter 2). If charitable works were performed in such a manner, there would be no place for either arrogance or cold charity.

Jian as simplicity and frugality can ensure the reduction of greedy heart. The second treasure of the Daoism Jian (俭) is closely related to $\mathrm{Pu}$ (朴 simplicity) and Jiejian (节俭 frugality, thriftiness). Although different from a legal charitable act (that is, to give direct help to the person in need), the way of Jian (俭) is to practise simplicity and thus ensure thriftiness and frugality in one's own life. Yet Jian (俭) can still be regarded as a charitable action to be carried out in a passive way. This paradox is explained by the requirement of Jian (俭) to live in a simple and non-extravagant way. In particular, the practitioner is asked to treasure any social and natural resources and to use them in an effective and non-wasteful way. Thus, true thrift and frugality can in turn ensure that more natural and social resources are made available, and can be gifted in charity for the use of other humans and other species. It is in this paradoxical sense that charitable work can be carried out without any trace of doing it. Laozi explains the paradox in this way: [14] 'Perfect activity leaves no track behind it; Perfect speech is like a jade-worker whose tool leaves no mark..... Thus, Sages fix on mastery at saving humans, so no human is abandoned; they fix on mastery at saving natural kinds, so no natural kinds are abandoned' (chapter 27). It is therefore for these reasons that to carry out charitable works without trace of having done so is seen as a higher level of charitable act within the way of Dao.

Why, then, simplicity and frugality as virtues can be regarded as a higher charitable work? In answer to this question, according to the Daoist understanding, the best way of resolving a problem is to avoid its happening, and to resolve it in advance before it actually becomes a problem. From this perspective, the modern charity model has actually resembled that of the modern western medicine, in the sense that all its attention is upon the symptoms where serious problems have already appeared rather than on potential problems in the way of prevention. Such a way of charity, from Daoist viewpoint, is not sustainable; because it can neither resolve the problem of poverty from its root, nor can it avoid the problem in advance.

What is the root of poverty? The biggest cause of poverty in my view is the shortage of social and natural resources, and the unequal or unbalanced distribution of the limited resources. Why does this inequality and imbalance occur? It seems to me that it is because of that driven by their greedy hearts and possessive desires, those who are stronger within human society have robbed the limited resources of the weaker and over-exploited the natural sources. It is suggested that most modern problems, such as the shortage of natural resources, the Greenhouse Effect, the serious conflicts and even terrible wars among nations, are all due to such greedy desires for maximum economic benefits, or due to the drive of the stronger to seize political power over the weaker. In the face of such a greedy desire and vanity, harmonious relationships between humans and nature, between countries and nations, are destroyed. If everybody, in each and every country, would simply 'look at simplicity and embrace frugality, lessening their selfishness and reducing their desire' (chapter 19), as Laozi suggests [14], most problems mentioned here could be resolved. If everyone could effectively use every single resource in their hands in an effective and non-wasteful way, more resources could be saved for helping others who are really in need. And this conservation of resources could effectively reduce the chance of pushing those who are weak into either the poverty trap or the conditions of suffering. Thus, although the way of Jian (俭) may not seem to advocate positive charitable action in terms of direct giving, its nature of saving and frugality will nevertheless pave the way for a positive charitable actions in a much wider sense, through reducing the greed of the human heart.

In fact, in comparison with the model where a little charitable help is offered after the action of big robbery of others or over exploit of the nature had done, the Daoist calling of 'return to simplicity' in order to leave more available resources for others is indeed a better action. To live in such simplicity could be a more effective way to keep society and the universe beyond in a sustainable and long-term balance. Based on this, Laozi declares 14]: 'The Dao is always fixed on a nameless way. Simplicity, although it is small, is greater than anything under heaven.' (chapter32). Thus, 'in managing humans and dealing with Nature, nothing outdoes conserving. To preserve is what we call early absorbing, and early absorbing is meant to emphasise storing virtuosity; emphasizing accumulation of virtuosity implies that everything will be subdued under its power..... This is called deepening its root and consolidating its base, a way of long life and enduring insight.' (chapter59). In this way, it has demonstrated that application of the second treasure 'Jian' could ensure the effective and sustainable performance of charity.

Bugan wei tianxia xian can ensure a necessary caution and a sense of respect in human heart. The third treasure of Daoism 'Bugan wei tianxia xia' can ensure that Daoist charity is performed as widely as possible, to the benefit of all beings under heaven. 'Bugan wei tianxia xia is literally translated as 'having the restraint not to seize the place that is first/pioneering/foremost' or 'having the courage and self-discipline to refrain from doing anything which no one in the world has done before '. For some critics, this Daoist 
ideal is to be worldly-wise and 'play safe', and can therefore be seen as timid, cowardly, overcautious, and showing lack of courage in attitude. However, it is suggested that such critics are in fact interpreting the phrase literally, rather than understanding it in the context of Daoist natural philosophy. The true meaning of the phrase is thus misunderstood. Its precise meaning can be most effectively demonstrated by the 'spirit of water', as described in chapter 8 of the Dao Dejing, where the saying is that [14]: 'the Highest Good is like water. Water is good at benefitting myriad things, yet it does not in itself contend; it settles itself at a place where others [may] repel or disdain. Hence it is close to the Dao' (chapter 8). The phrase 'Bugan wei tianxia xia' thus deliberately enhances a virtue that is nourishing for those who are already part of the holistic world, but which is disdained by those who hold such a world in contempt. Practitioners must thus follow the way of the Dao in 'non-acting', 'yet myriad things are done through her'. Furthermore (and very importantly), [14] 'if a stillness has been obtained through lack of desire, the whole world will be stabilized' (chapter 37). Thus, non-action and non-desire are not only effective in enabling myriad thing to grow, but are also beneficial for the doer him or herself: [14]

The one who does not push forwards the self will be luminous; the one who does not regard the self as infallible will be conspicuous; the one who does not engage in self-harm will have success, and the one who does not boast will grow. Hence, if only one does not contend, there will be no one under heaven who can contend with him (chapter 22).

Two great values are embedded within this Daoist phrase, which the current world has lost: a necessary caution when an action is initiated, and the necessary fear and respect that one should have when one dealing with a target object and initiating an act upon it. Daoism is not a tradition lacking in imagination, creativity and freedom of thought. It does however warn people to be cautious in action, simply to avoid the possible harmful impact that could be caused by prodigious feelings of self-importance, as Laozi explains: [14] 'Those who have previously mastered [themselves] to be a good scholar will be cautious in action, as if they are crossing a stream in the winter season; they will hesitate as if in deference to the neighbours around them' (chapter 15). Hence, the Daoism believes that 'what people must fear are those that humans need to be feared'. In other words, those doers should always approach their doing action with caution, and assume that 'there may be something harmful which remains hidden, and which has not yet made its appearance.' (chapter20).

The proposition is therefore as follows. One of the greatest problems of humankind in our modern era is that they fear nothing. They display enormous arrogance, and appear to feel that they are alone in being the most important species in the world; there can be no other species or beings with equal significance. Therefore, they should be the centre of the world; everything of the universe should thus be subdued by their will and desires, and offer their services and their obedience to them of their own free will. This self-important tyranny has brought those in power to believe that only they have the truth, and that only they are blessed by God. Therefore they have the right to do whatever they wish to others, whom they see as being in an inferior position. They have neither respect towards their ancestors, nor gratitude to their Earth Mother; neither reverence towards the Nature, nor shame for the destruction of any existing harmonious relationship in both society and the natural world. This fearless and towering determination, plus a fierce desire to control, has seemingly caused humankind in this era to not only lose their sense of reverence and humility, but also their sense of respect. As a result of these fearless exploits, however, our Heavenly Father's perfect skin (the ozonosphere) is broken; our Earth Mother's body is full of scars. Laozi therefore warns that [14] 'those whose bravery lies in daring will be slain; those whose bravery lies in daring will not live.... The Way of Heaven is not to contend but to be expert in defeat'(chapter 37).

Thus, this necessary sense of caution, fear and reverence as embedded within the third of the three Daoist treasures may not result in a direct donating action of gifts and money as set out in the 2011 charitable definition. Its power is much greater, however, in ensuring that the practitioner carries out the practice of frugality and passing on surplus to the needy in a spirit of respect and compassion, rather than with coldness and disdain. In the same way, the third principle counsels the use of a sense of caution and reverence to ensure care when initiating anything which may hide potential threat or harmful impact upon either humankind in general, or the natural world. By doing so, the intent is to ensure that anything that needs to be done is done in a proper and considerate manner, as Zhuangzi states: [19] 'We allow the world to be itself, fearful of spoiling its innate nature; we leave it alone, fearful of those who adversely affect the world's Virtue. [Thus], if the nature of everything under Heaven is not distorted, [and] if the world's Virtue is not despoiled, then what need is there to govern the world?'(p.82).

Bugan wei tianxia xian is also the manifestation of the Daoist nature-centred worldview. As described in chapter 25 of the Dao Dejing [14] 'Humans follow the Way of the Earth; the Earth follows the Way of Heaven, and Heaven follows the Way of Nature.' This tells us that the picture of the world is a holistic one, in which humans are only part of the picture and they are not superior beings to be favoured by the Dao or the heaven and earth. Separate from Nature, yes, but an integral part of nature; the human world and the world of Nature are therefore unified together as a holistic Oneness. For Daoism, myriad things (including humans) are produced by the Dao and reared by the inner power (De). Thus, since Nature is the essence of the Dao, so everything to be created by the Dao should follow the destiny of Nature: [14]

The Dao gave birth to them (myriad things) and the virtue (inner power of the Dao) cultivated them, they are shaped to their physical form based on their specific nature and perfectly completed according to their own 
strength and circumstance. For this reason, there is no single one among the ten thousand kinds who does not follow the Dao and value the virtuosity. The reason why the Dao should be respected and virtue should be valued is because they are not coerced but always act in a natural way (chapter 51).

This natural way is the way of autonomous spontaneity. From the Daoist perspective, a man with high developed wisdom, and giving pure unconditional parental love to the world (such as the Sages) will do what others will not do, and pick up what others have ignored. $\mathrm{He} / \mathrm{she}$ will only assist the ten thousands things to fully develop the potential that is inscribed within them by their inner nature; they will dare not do what is not in the natural category that may have the potential to destroy the natural order: [14]

So Sages desires what people do not desire, and do not value those good things that are not easy to get; they study what people do not study, and revert to what people have overlooked. By behaving in this way, they reinforce the spontaneous nature of myriad things rather than daring to engage with any sort of manmade creation (chapter 64).

To respect the natural order and our Earth Mother in this way is becoming ever more urgent, with environmental problems becoming more serious day by day. The serious outcome of our wanton plundering of our planet's natural resources, and abuse of our Mother Earth has become more and more disturbing. In particular, the immoral uses to which scientific discoveries have been put causes increasingly serious problems. The arbitrary use of what humans make of their gift of free will, of their ever-growing conceit and the excesses of greed in their hearts, are all behaviours that centre on satisfying the uncontrolled desires of the self. The result of these behavours is a terrible separation of human beings from Nature, far away from her nourishment. This separation, brought about by humans themselves, cannot be resolved unless their destructive attitude toward nature changes. From this perspective, following the Daoist nature-centred principles, philosophy and physical and spiritual exercises, can provide an effective tool for damaged humans to repair themselves, as well as to rebuild proper relationships with the natural world that they have so badly harmed, leading in turn to profound philosophical principles on which to base environmental protection related charitable acts.

\section{Equality among all beings and the heart of compassion in Daoism}

The centrality of charity and compassion in Daoism can be also manifested in its principle of equality amongst all beings, which extends not only the rights of animals and other species on earth, but also beyond, to other beings in the universe. As seen, Daoism holds a Dao centred world view, meaning that Dao is the ultimate source of the universe. In other words, all beings that exist in this world (including every life form) are manifestations of the Dao, through its first material manifestation, that is, the Prenatal Qi. Different beings in this universe therefore differ only because of their varying stages of completion within the Qi. Yet they are all equal in the eyes of the Dao, as they all have their origins in the Qi. Within this cosmological understanding, human beings are therefore as one with animals and of any other beings in the Daoist universe; none has priority. Hence, it follows that humans have no right to abuse either animals or any other species in the universe. Nor have they any right to abuse each other. In the same way, humans themselves are all equal, no matter how differently they regard their ranks and gender. Thus, the principle of protecting the weak in both human society and the natural world is integral to Daoism. More importantly, these Daoist principles are becoming more and more significant in the newly developed 'legal concept' of charitable works.

\section{The strong focus of healthy longevity yangsheng and Daoist spirit of charity}

The final but not the last piece of evidence regarding the spirit of charity and compassion at the heart of Daoism is the strong focus on happy and healthy longevity, and in terms of this, Daoism is distinct from any other world religion. The aim of Daoist religion is to encourage its practitioners to attain the Dao, and to achieve an Oneness with this great Source of all living things, and thus become an immortal or a true-being. In this way, Daoism affirms the capability of humans to become a transcendent being by their own personal effort. This Daoist affirmation in turn manifests its special understanding of the value of the myriad forms of life, and the close relationship between all living things and the Dao itself: [20]

The Dao cannot be seen unless it is manifested in the form of life; life cannot be lasting unless it is under the protection of the Dao. Hence, if life has gone, the Dao would disappear; and if the Dao has disappeared, life would die out.'

Amongst all life forms, it is human life that is the most treasured, as it is composed of both yin and yang, and possesses both physical body and invisible spirit. Tao Hongjing [21] declares: 'Humans not only have $Q i$ but also Spirit which makes them the most precious beings, and therefore, the most important thing for human beings should be their lives.' In other words, humankind not only has ability to comprehend the nature of the Dao, but also the potential to transmit the Dao and make it manifested. In order to fully develop these remarkable abilities, humans need to prolong their lives for as long as possible, living healthily and frugally, and striving always to attain Oneness with the Dao.

However, as it is written [22], 'although the Dao never neglects humans, yet humans often violate the Dao; although life never lets humans go, yet humans often let life go'. Thus, in order to enable the practitioner to attain the Dao and to become as One with the Dao, three systems of exercises have been created by the Daoist religion; among them, the first 
one focus on healing illness, the second one focus one healthy longevity, while the third one focus on achieving of immortality. In this way, cultivating of healthy longevity, even immortality life, is closely connected with the obtaining of the Dao, as Laojun miaozhen jing explains: [22]

People who engage in nourishing life cultivation need to be extremely careful in not losing the Dao, while the people who are cultivating the Dao need trying hard not to lose their lives. Both must let the Dao and the Life maintaining each other, and let the life and the Dao protecting each other.

Such nourishing life cultivation is not only important for the individual who practise it, but also for the manifestation and the prevailing of the Dao through them. It is for this reason that the early Daoist religious scriptures (Laozi Xianger commentary) [23] used the concept of 'Life' to replace that of the 'King' when interpreting the 'Four Greatnesses' of Dao Dejing. Thus, 'the Dao, the Heaven, the Earth and the King' are replaced by 'the Dao, the Heaven, the Earth and the Life', and in this way life become one of the four greatest things in the world and become 'another body of the Dao.'(p.46). Based on such an understanding, the Scripture of the Great Peace [24] declaims that 'life is the foremost issue that need to be emphasized' (p.613). Ge Hong [25] of the Jin Dynasty gives a clearer expression of the preciousness of life as follows: '[since] the greatest virtue of Heaven and Earth is generation of life and so life is being excellence' (p.326). Hence he [25] insists that 'what Daoism emphasises most is nothing but the development of the skills of longevity (p.327). Thus, as we have seen, Daoists fully believe that humans can attain everlasting life through personal effort in unifying one's own life with the Dao.

It is written that the reason why human have this capacity to prolong their lives is mainly due to the 'Dao of the Humans' being distinct from the Dao of Heaven. In other words, although individual humans can do nothing about their physical shapes or quality of intelligence, as these are features that have been inscribed into each being by nature through their parents; however, the choice to live one's life either with a strong physical body or a weak one, with a short lifespan or a long one, is entirely dependent on oneself. This choice is expressed in the famous Daoist maxim 'My Life is in my hands, not in the hands of Heaven'. In Zhenqi Huanyuan Ming [26] this maxim is interpreted in this way:

[This maxim] speaks of the life and death of the human being as being decided by the individual's own choices. If people could become one with the Dao of the Nature, could circulate the $Q i$ to return it to its original harmonious state, could swallow the Two Scenes ${ }^{1}$ from outside and intake the Five Sprouts ${ }^{2}$ from within, control a hundred spirits in one movement, and keep

\footnotetext{
${ }^{1}$ Two scenes refer to the change of the nature from yin to yang or yang to

yin. 2 The Five Sprouts refers to the five life forces generated by the five internal organ systems (the Liver, the Lungs, the Heart, the Kidneys and the Spleen) that connected to the five directions: the East, west, south, north and middle.
}

internal organs undisturbed when still, then they will neither be violated by either cold or heat, nor by hunger or thirst; nor will they be harmed by the five sharp weapon. If only one can hold life and death in one's hands, one can change according [the will of] one's heart, therefore the earth cannot bury him/her, while the heaven cannot end her/him. This is what is meant by the maxim 'my life is in my hands, not in the hands of heaven.'

From Daoist understanding,[25] if only the practitioner can maintain the prenatal $Q i$ in all its fullness and refrain from self-indulgence such as overeating, too much vibrancy of sound and colour, and sexual excess, and so on, he or she can live close to nature in healthy longevity; otherwise, if there is no attention to proper diet or appreciation of sexuality, vital forces will become exhausted and life energies will decline, then death at a young age will be resulted (Vol. 1). Thus, from the emphasis of the need for humans to follow the Way of Nature and the affirmation of the capability of humans in understanding the essence of Nature, the Daoist religion therefore encourage people to apply the Dao of Nature to their daily lives, so as to prolong their individual life span. This is the reason why Yinfu Jing (阴符经) [27] counsels the Daoist practitioners to 'Observe the Dao of Heaven and follow the Acts of Heaven,' and believes that 'because the Sages knew that the Dao of Nature could not be violated, therefore formulated it.' Based on such a belief, Daoist practitioners have made much of their inherited skills embedded in traditional Chinese medicine, and their expertise in Daoist yangsheng exercise for sustaining their happy and healthy longevity lives.

Throughout the course of history, generations after generations of Daoist practitioners have developed further new skills to add those already in existence. These are skills and techniques that have become an integral part of daily Daoist self-cultivation and natural lifestyle, which are the outward expression of their deepest inner understanding of the Daoist philosophy. Among the three levels of DIY Daoist yangsheng exercises, the self-healing exercise which aims at the healing of disease, recovery of illness, and restoration to full health and well-being, is at the lower end of the Daoist exercise system. The healthy longevity self-care exercise is at the middle level, aim to enhance health and attain happy longevity life through preventing illness before it actually occurs. The immortality exercises aiming at attaining life everlasting and spiritual transcendence are at the highest level of Daoist Yangsheng practice. At this level, however, exercises are complex, and demand of the practitioners' whole attention to their practices, which may not be possible for lay people living in a secular society, with daily responsibilities toward both family and immediate community, to practice. Nevertheless, the self-healing and self-health-care exercises for healthy longevity can be practiced by ordinary people in their daily lives and activities. Indeed, these are exercises that have been practised for thousands of years, not only by the Chinese, but also by the 
people of East Asia, as part of their lifestyle; not only by people of different ages and genders but also by people under different health conditions.

\section{Conclusion: Transforming the Daoist Charitable Spirit into Charity Work}

As we have seen that Daoism is unique in its particular spirit of charity and heart of compassion. Daoism also takes these elements both to a higher and wider level than its modern counterparts, as well as to a dimension underneath and unseen, in order to examine the roots and causes of each problem that needs to be addressed. The central concept of Dao thus guides practitioners to look for the real nature and meaning of life across all different life forms and beings. Its goal of unifying individual life with the Dao will encourage humans to look inward, to seek the essence of their inner nature; it will also encourage each one to connect with their innate nature to live a simple and contented life. We have also seen that amongst the three treasures of Daoism, $C i$ as parental love will ensure that charitable work is carried out in a kind, gentle and considerate way, and encourage practitioners to act bravely in order to protect both the human species and those myriad species away from dangers. Jian as counselling simplicity, frugality and thriftiness, will encourage humans to use the minimum of social and natural resources on the one hand, and, on the other, to pass on to those in need as much surplus as possible for those generations living alongside us, both in the present and in the future. Thirdly, Bugan wei tianxia xian (daring not to lead the world) will ensure that practitioners develop a sense of fear, reverence, humility and respect in dealing with human relationships and those in the natural world. The application of these principles will therefore ensure that Daoist charitable works include careful attention to the roots and causes of the problem of poverty from its origin in order to carry out effective solutions. Such restraint and humbleness will reduce the potential risks that result from unthinking arrogance, self-important attitudes and selfish behaviours.

The Daoist nature-centred worldview teaches a holistic picture of both human and natural world relationships and therefore places protection of the natural environmental protection and equality among its different life forms at the centre of its philosophy. In other words, the core teaching that all life forms are to be treasured leads in turn to a strong emphasis on life protection, health enhancement, and the pursuit of longevity and well-being. The Daoist skills and techniques of nourishing life inherited from ancient Chinese tradition, invented through personal cultivation along thousands of years of history, also provide Daoist disciples with particular tools to enable a unique contribution to the modern concept of charitable works.

What, then, should Daoists do in order to establish their own unique way of contributing to charitable works? In answer to this question, an examination of the history of this movement in modern western societies demonstrates that the attraction of Daoism is based on its nature-centred and holistic worldview and its philosophy of life, as well as the unique bodily and spiritual exercises that teaches what so called as the way of Yangsheng (or nourishing life), which can promote one's healthy longevity pursuit. ${ }^{3}$ Suggestions for ways forward are therefore as follows: firstly, part of Daoist education needs to open its doors to the society. Secondly, a systematic training system for Daoist Monks needs to be put in place from within. Finally, the unique characteristics of the Yangsheng (nourishing life) system of exercises need to be established as a specialist Daoist charity to enhance health and life care, and to promote and teach environmental and moral care to the general public.

However, in comparison with Christian and Buddhist education, Daoist education in both China and the West is lagging behind. There are various reasons for this situation. As one example, the Nature-based principles of Daoism do not encourage its practitioners to preach 'the way' to those who are indifferent this tradition. For the Daoists, in fact, not everyone can be admitted into their midst. Their doors are only opened to those who aspire to learn of the Dao, and possess the enthusiasm and purity of heart to do so. Thus, it is an education that would never be forced or imposed in an attempt to 'convert', as has been the case in the spread of Christianity and Buddhism, for example.

More than this, the skills of the Daoist way to the cultivation of channels toward immortality are kept as inner secrets due to its potential power of transcendence. They can only be passed down with care to those who possess compassionate hearts and highly developed virtue; because of the fear that if these skills were delivered to those of low virtue, with hearts of violence who in turn put these skills to improper use, then great harm could be done to human society. The master who has developed these skills in improper disciples would have to take responsibility for transmission of the Dao in proper hands; otherwise, they will be liable for severe punishment from heaven. This is the reason why Daoist masters must find fitting disciples to carry on their skills and techniques, not simply enrol as many disciples as possible. Because of the strict rules in the transmitting of the Dao, there are therefore far fewer experts in Daoism than in other traditions, such as Christianity and Buddhism.

Furthermore, because these unique skills are taught in a secret way to a small number of chosen disciples, there are not sufficient numbers to set up Daoist education even for its internal training. Because the majority are unable to access it, few can understand it, and even fewer can promote it to the public. These complexities put Daoism in a situation of having far fewer disciples than those of Buddhism and Christianity, even far fewer educators than the other world religions. This has become the largest barrier in the way of establishing of Daoist Charity. To make its spirit of charity shine out and manifest its heart of compassion, Daoist practitioners thus need to gather their strength to remove this

\footnotetext{
${ }^{3}$ See Yanxia Zhao: Why Daoism? Daoism in the West since the 1970s.
} 
huge barrier of stone which has blocked its way to modernization and charity.

In order to establish the Daoist way of charity, a rational reform of Daoism in education is indeed needed. How can such sort of reform be attempted? My personal answer is: the Daoist education must learn to open its doors to those who are interested in Daoist philosophy and religion, and to provide opportunities for them to study deeper knowledge of Daoist tradition. In this way, they may find among those who come to them potential good disciples, who possess the wisdom and purity of heart to progress to the learning of the inner secrets of Dao. Their numbers may thus begin to swell to the point where disciples-in-training may come forwards to teach to the general public the system of Yangsheng (nourishing life) exercises for self-healing and longevity, from a well-informed base. This might be one possible solution to the problem of how the vital charitable works discussed above can begin.

At the same time, those recruits who are able to progress to the higher spiritual levels will learn how Daoism came into being, and developed through history. They will study the five ways for enlightenment (the so-called 'five vehicles of the law') as follows: the ancestor root (Zong 宗, direct enlightenment through connecting with the truth revealed by Laozi and Zhuangzi); teaching (Jiao 教, enlightenment through learning and understanding of the Daoist teachings); disciplines ( $\mathrm{Lu}$ 律, enlightenment through following the Daoist discipline, in order to gain higher wisdom from daily meditation); law/rule (Law 法, enlightenment through participation in the particular ways of a Daoist sect) and ritual ( $\mathrm{Ke}$ (科, to gain enlightenment through taking part in Daoist rituals and ceremonies, and charting of Daoist Religious Texts). Through such internal training from within, existing Daoist Monks can train new disciples to reach a higher level in both their understanding of Daoist texts and in Daoist daily cultivation of spirituality. Thus, when the standards of Daoist education from within are promoted and progressed in this way, then the teaching resources of public Daoist Education will be in a better position to carry out the charitable works discussed in this paper.

Another thing need to be noticed is that although there are too few Daoist colleges are available for both Daoist Monks and for lay people in current time, there are, however, commercial Daoist educational activities taking place elsewhere, for example, undertaken by westerners who learned from Chinese nationals in the west, or Chinese none-Daoist organizations in China; although a well-organized Daoist education system is far from being established, yet the rise of western studies in Daoism has coincided with the coming of the Internet, which have made Daoist classes and exercises available for public access from online. Thus, highly commercialised exposure of the inner spiritual secrets of Daoist tradition is unfortunately unavoidable. Guarding Daoist secrets for those who are fitting and pure of heart is thus becoming harder and harder. To against such a background it also calls to develop and to modernise Daoism in an urgent way. It will be seen that such reform is no longer a question of 'to be' or 'not to be', but a question of 'how' and 'when'.

From my point of view, the 'how' and the 'when' should concerns three different levels. On one level, I suggest that those skills that cultivate immortality (together with other techniques related to cultivation of physical and mental powers) should not be put into the hands of the violent, the immoral, and the power-hungry. Such skills should continue to be closely guarded within the Daoist tradition, and to be made available only to those who have both the wisdom and the morality to transmit the Dao.

On a more public and charitable level, however, the Daoist skills of self-healing; the techniques of healthy longevity; the positive attitude to life; the non-action philosophy; the natural worldview, and the equality between humans and between the human world and natural world, which have been practiced by the Chinese and East Asian societies for thousands of years in the past, should be no longer to be held as secrets. These are the teachings that should be revealed to the general public, for which they should have free access.

The opening up of these teachings by authentic Daoists is even more important in the light the unethical internet practice mentioned above, where online classes are offered for profit by those with only partial knowledge and skills. The unfortunate fact is that whether or not the Daoist tradition wishes to open up its inner secrets to the public, the current age is one which no longer allows the keeping of secret knowledge and practice. The Daoist system of exercises known as Yangshen (nourishing life) will come to light sooner or later through different channels, even if Daoism itself is not willing to reveal them. It has therefore become a matter of urgency to establish a standard Daoist educational institution to deliver the correct knowledge and skills to enable the recovery, building up and maintenance of personal health, so that all may learn how to take care of their own lives, and harmonise their own relationships with both human society and the natural environment.

Based on that, I propose that to take building up teaching resources as the most urgent element of Daoist modern reform, which is as a matter of central importance to the Daoist works of charity. Existing Daoist organizations therefore need to organise various kinds of essential training by opening their doors to selected novitiates, as suggested above. There are different ways towards the Dao and to be one with the Dao; in the same way, Daoists will need to provide for a wide range of differing learning approaches and channels for those who come to them with problems of physical, mental and spiritual health. The world has great need of the Daoist nature-centred approach and techniques for physical, mental and spiritual healing, and for healthy longevity. It is time for the Daoist disciples and practitioners to descend from the remote mountains of China and take up the charitable work of healing and balancing the world by opening up their way to the ordinary people! 


\section{REFERENCES}

[1] Longman Dictionary of Contemporary English, New Edition, Beijing: Foreign Language Teaching and Research Press, 2004

[2] Commissioners for Special Purposes of Income Tax v Pemsel, 1891

[3] G W Keeton, 'The Charity Muddle', 2 Current Legal Problems 86, 1949

[4] Matthew Harding, Ann O'Connell, Miranda Stewart, Joyce Chia, 'Defining Charity: A Literature Review' published by Melbourne Law School at www.law.unimelb.edu.au/3E4618 E0-A491-11E1-8C420050568D0140 accessed at 2014-09-09 9:27

[5] Gareth H Jones, History of the Law of Charity, 1532-1827, Cambridge University Press, 1969

[6] Charities Act 2011, http://www.charitycommission.gov.uk/d etailed-guidance/charitable-purposes-and-public-benefit/guid ance-on-charitable-purposes/\#sthash.YZeCWMt7.dpuf

[7] Christian Smith and Hilary Davidson, The Paradox of Generosity: Giving We Receive, Grasping We Lose, Oxford University Press, 2014

[8] Thomas Aquinas, Summa, Theologica, Translated by Fathers of the English Dominican Province, Benziger Bros. edition, 1947

[9] Immanuel Kant, Lectures on Ethics, translated by Louis Infield, London: The Century Co., 1930

[10] Aristotle, Politics, translated by T. A. Sinclair, First Published in London: Penguin Books Ltd, 1962

[11] Chak Kwan Chan, 'Caring for the poor versus degrading the poor - the case of Hong Kong newspaper charity', in the International Journal of Social Welfare, Balckwell Publishing, 2004, Volume 13, pp.266-275.

[12] Robert D. Lupton, Toxic Charity: How Churches and Charities Hurt Those They Help (And How to Reverse It), New York: Harper Collins Publishers, 2011.

[13] Jonathan Edwards, Charity and Its Fruit: Christian Love as Manifested in the Heart and Love, James Nisbet \& Co., 1852
[14] Laozi 老子, Dao Te Ching 道德经, in Heshang gong Commentary of Daode jing, 老子道德经河上公章句, zhonghua shuju 中华书局, 1993

[15] Richard Stupart, '7 worst international aid ideas', $\mathrm{http}: / /$ matadornetwork.com/change/7-worst-international-aid -ideas/ access at 2014-11-04 12:50pm

[16] Zizek, 'donations to charity are hypocritical', http://matadornetwork.com/change/zizek-says-your-donation s-to-charity-are-hypocritical/ access on date 2014-11-04,12:50pm.

[17] Arthur Waley, Laotzu Tao Te Ching, Wordsworth Classics of World Literature, 1997

[18] YangTianyu 杨天宇, Liji Yizhu 礼记译著, shanghai guji chubanshe上海古籍出版社, 2007

[19] M. Palmer (tr.) The Book of Chuang Tzu. Penguin Classics, 2006

[20] Taishang Laojun Neiguan Jing 太上老君内观经 in Daoist Cannon 正统道藏, Book No.342, part Dongshen, catalogue: original text, Vol.1

[21] Tao Hongjing 陶弘景, Record on Nourishing Inner Nature and Extending Life 養 性 延 命 錄 ', http://www.ctcwri.idv.tw/CTCW-CJD/CJD03\%E6\%B4\%9E $\% \mathrm{E} 7 \% \mathrm{~A} 5 \% 9 \mathrm{E} \% \mathrm{E} 9 \% 83 \% \mathrm{~A} 8 / \mathrm{CJD} 0308 \% \mathrm{E} 6 \% \mathrm{~B} 4 \% 9 \mathrm{E} \% \mathrm{E} 7 \%$ A5\%9E\%E6\%96\%B9\%E6\%B3\%95/CJD0308ALL/CJD030 $822 \% \mathrm{E} 9 \% \mathrm{~A} 4 \% 8 \mathrm{~A} \% \mathrm{E} 6 \% 80 \% \mathrm{~A} 7 \% \mathrm{E} 5 \% \mathrm{BB} \% \mathrm{~B} 6 \% \mathrm{E} 5 \% 91 \%$ BD\%E9\%8C\%84/CJD030822-1\%E9\%A4\%8A\%E6\%80\%A 7\%E5\%BB\%B6\%E5\%91\%BD\%E9\%8C\%84\%E5\%8D\%B7 $\%$ E4\%B8\%8A.pdf

[22] laojun miaozhen jing 老君妙真经, quoted by Tao Hongjing in Record on Nourishing Inner Nature and Extending Life 養 性延命錄

[23] Rao Zongyi 饒宗頣: Laozi Xianger Zhu jiaozheng 老子想爾 注校證, Shanghai Guji Chubanshe 上海古籍出版社,1991

[24] Scripture of Great Peace, in Wang Ming 王明: Taiping Jing hejiao 太平經合校: Zhong Hua Shuju 中華書局,1960

[25] Ge Hong 葛洪, Bao Pu zi 抱朴子, vol. 14, in Wang ming 王明: 《抱樸子內篇校釋》, 中華書局, 1985

[26] Zhenqi Huan Yuan Ming 真气还原铭, http://ctext.org/library.pl?if=gb\&res=83927\&remap $=\mathrm{gb}$

[27] Huangdi Yin Fu Jing 黄帝陰符經， http://ctext.org/yinfujing 